\title{
A new small deinonychosaur (Dinosauria: Theropoda) from the Late Cretaceous of Patagonia, Argentina
}

\author{
JUAN D. PORFIRI, JORGE O. CALVO and DOMENICA DOS SANTOS \\ Centro Paleontológico Lago Barreales (CePaLB), Universidad Nacional Del Comahue \\ Ruta Provincial 51, Km 65, Neuquén, Argentina \\ Manuscript received on February 2, 2010; accepted for publication on September 14, 2010
}

\begin{abstract}
Here we report on a new small deinonychosaurian theropod, Pamparaptor micros gen. et sp. nov., from the Late Cretaceous of Patagonia, Argentina. Pamparaptor micros exhibits a pedal structure previously unknown among South American deinonychosaurians. The new material provides new evidence about the morphology and taxonomic diversity of Patagonian deinonychosaurs. Pamparaptor is the smaller non-avialae Patagonian deinonychosaur, probably with about 0.50-0.70 meters, long. The pedal construction resembles, that of Troodontid or basal Dromaeosaurids. Nevertheless, up to now, we considered Pamparaptor a peculiar Patagonian Dromaeosaurid with troodontid-like pes.
\end{abstract}

Key words: Argentina, Barreales Lake, Dromaeosauridae, Late Cretaceous, Patagonia, Unenlagiinae.

\section{INTRODUCTION}

During the last decade, the fossil record of deinonychosaurian theropods from Patagonia has notably increased. Up to now, the records of Deinonychosauria from Patagonia include Unenlagia comahuensis (Novas and Puerta 1997), Unenlagia paynemili (Calvo et al. 2004), Neuquenraptor argentinus (Novas and Pol 2005), Buitreraptor gonzalezorum (Makovicky et al. 2005) and Austroraptor cabazai (Novas et al. 2008). Here we report on a new deinonychosaurian, Pamparaptor micros gen. nov sp. nov, collected from the Baal quarry, at the north coast of Barreales Lake, Neuquén, Argentina (Fig. 1). The specimen comes from the Portezuelo Formation, (Turonian-Coniacian), Neuquén Group, and it is represented by pedal elements. The new form is gracile and small, with about $0.50-0.70$ meters, and its metatarsal construction is highly derived, resembling troodontids (Xu and Wang 2000). We offer here a brief description of this notable discovery.

Proceedings of the Third Gondwanan Dinosaur Symposium Correspondence to: Juan D. Porfiri

E-mail: jporfiri@yahoo.com

\section{SYSTEMATIC PALEONTOLOGY}

SAURISCHIA Seeley, 1887

THEROPODA Marsh, 1881

DeinOnychosauria Colbert and Russell, 1969

Pamparaptor micros new taxon

Etymology: Pampa, in honor to the Indian Pampas that lived in the central plain of Argentina; and raptor, robber in Greek; micros, for the small size of specimen.

Holotype: The holotype MUCPv-1163 (Figs. 2-3) is represented by an articulated left foot including wellpreserved metatarsals II, III and IV, complete digit II, phalanges III-1, III-2 (well-preserved), and incomplete phalanges IV-2 and IV-3. The specimen was found in 2005 by Mr. Diego Rosales who is the technician of the Centro Paleontológico Lago Barreales (CePaLB), Universidad Nacional del Comahue.

Horizon, age and locality: The Portezuelo Formation, Río Neuquén Subgroup, Neuquén Group, Upper Cretaceous, Turonian-Coniacian (Leanza et al. 2004). The material cames from the Baal quarry on the north coast 

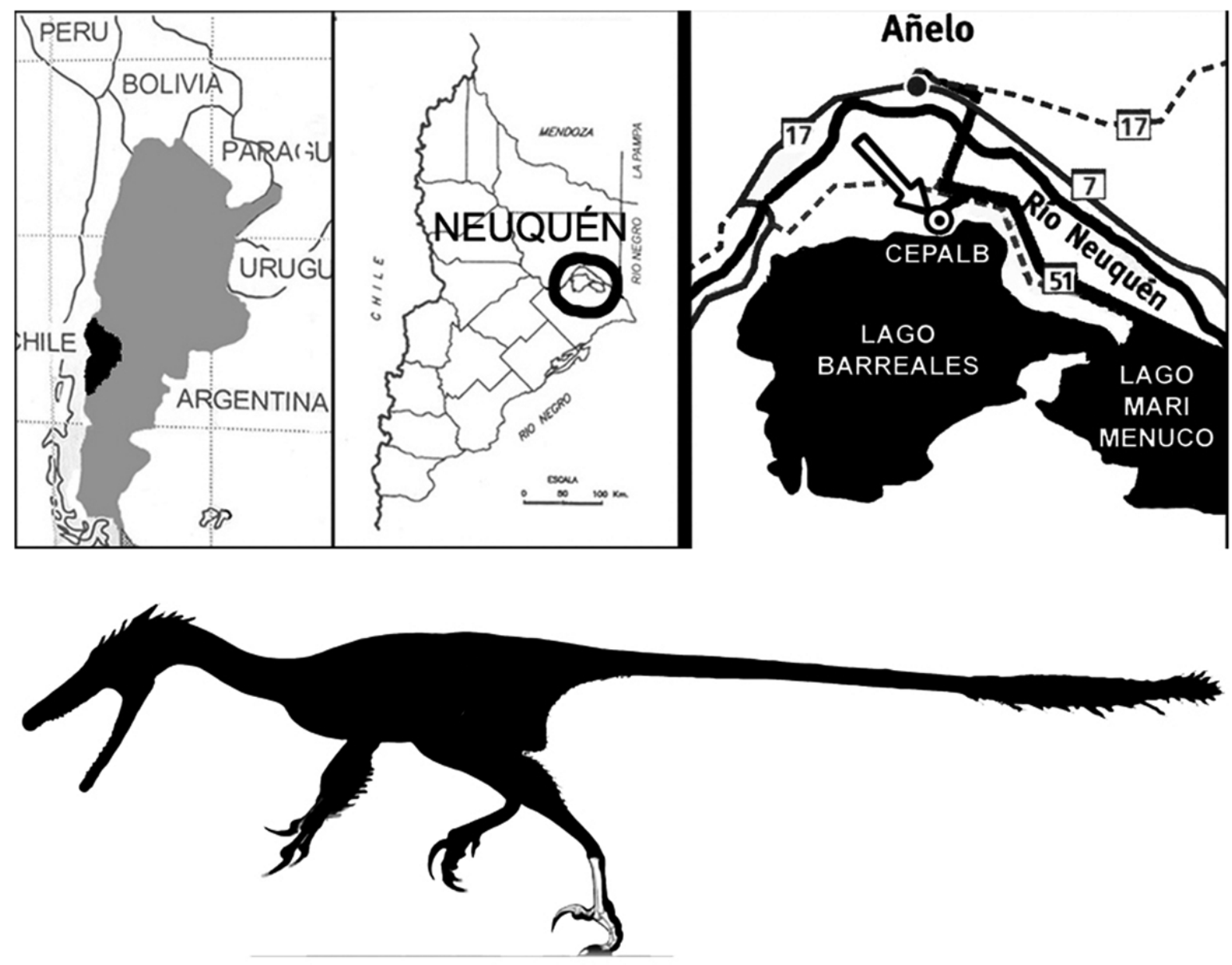

Fig. 1 - Map showing the locality of Pamparaptor.

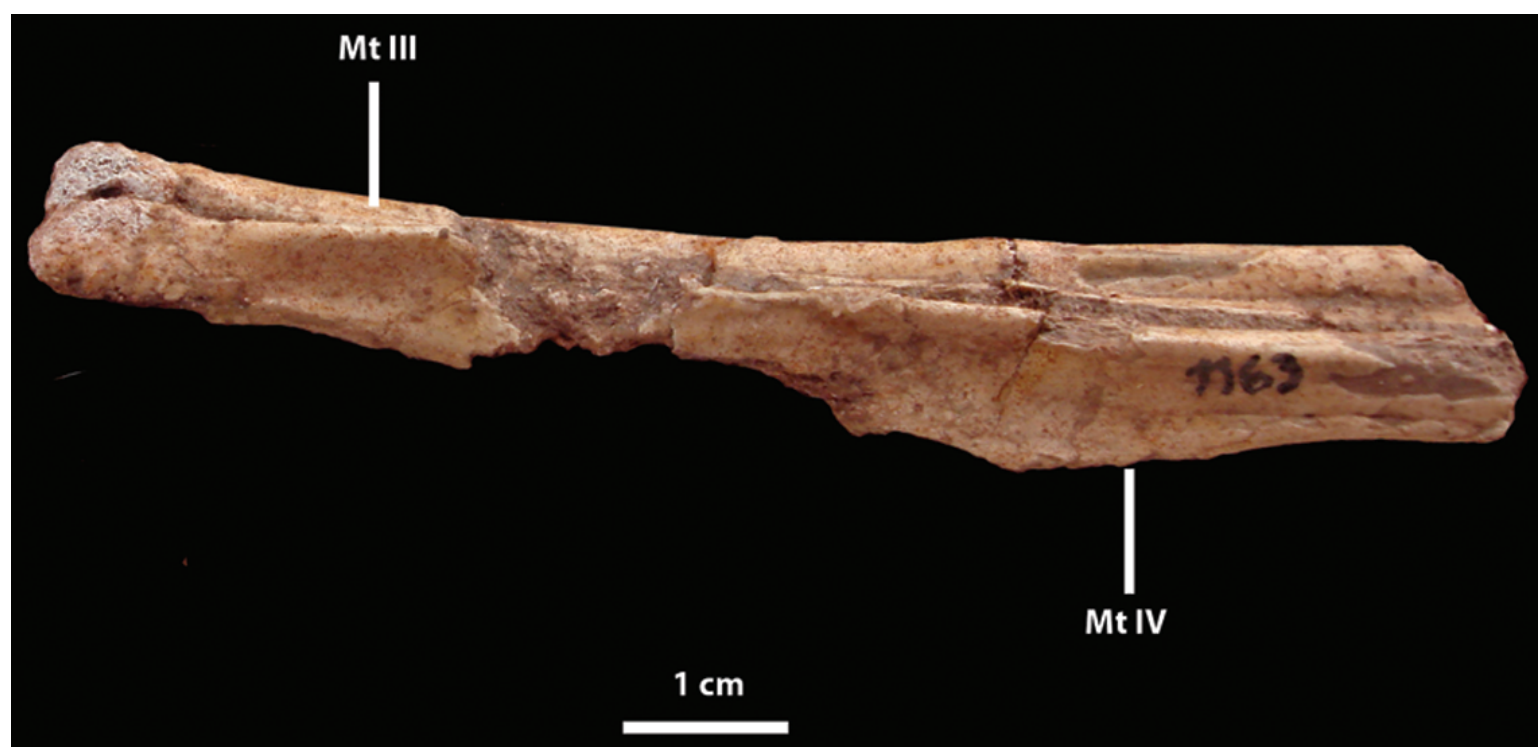

Fig. 2 - Metatarsals in lateral view. 


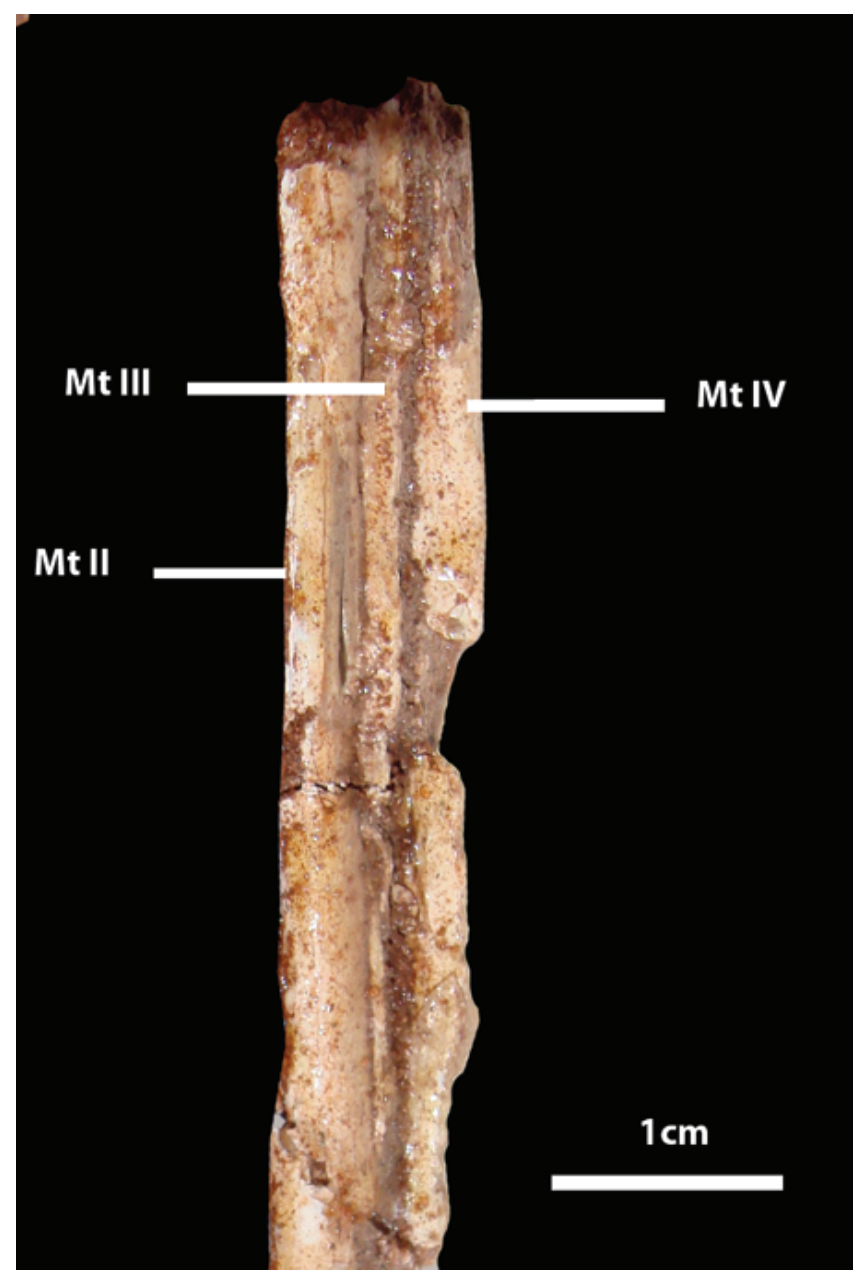

Fig. 3 - Proximal end of metatarsals in anterior view.

of Barreales Lake, at 90 kilometers NW of Neuquén city, Neuquén province, Patagonia, Argentina. Up to now, the record of dinosaurs collected in the Portezuelo Formation includes the giant lognkosaurian titanosaur Futalognkosaurus dukei (Calvo et al. 2007), the dromaeosaurids Unenlagia comahuensis (Novas and Puerta 1997), Unenlagia paynemili (Calvo et al. 2004), and Neuquenraptor argentinus (Novas and Pol 2005), the alvarezsaurid Patagonykus puertai (Novas 1997), the allosauroid Megaraptor namuhnuaiquii (Novas 1998), as well as abelisaurids remains (Novas et al. 2006, Juárez Valieri et al. 2008), undescribed theropods (Porfiri et al. 2005), and fragmentary remains of a possible neornithine bird (Agnolín et al. 2006).

Diagnosis: Pamparaptor micros distinguishes from other deinonychosaurians in the following combination of features: slender metatarsus construction with metatarsals IV strongly compressed transversely on its distal half, acquiring a blade-like shape in caudal view; metatarsals IV and III subequal in length; proximal half of metatarsal III narrow and with subparalel margins along its length; metatarsal III lacking a distal ginglymus; metatarsal II distally overlapping metatarsal III; proximally, metatarsal II is approximately twice the wide of either metatarsals III and IV; phalanx 2.II longer than phalanx 2.I; in cranial view, distal end of metatarsal II with a small sulcus medially directed.

Description and comparison: The articulated left foot is well preserved (MUCPv-1163). The metatarsal III is 9.3 centimeters long, thus suggesting that the whole lenght of the animal was approximately 0.50 0.70 meters. 


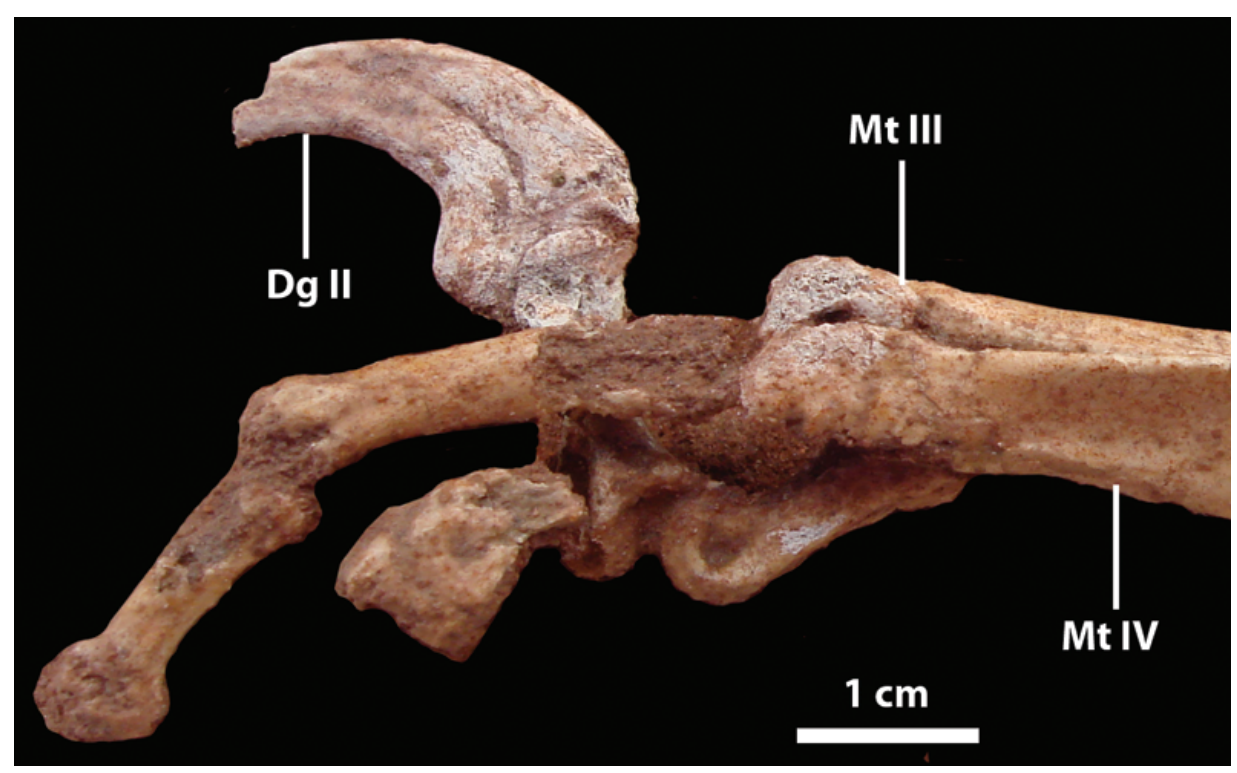

Fig. 4 - Distal end of metatarsals, phalanges and claw in lateral view.

The first and fifth metatarsals are absent. Metatarsal II is shorter than metatarsals III and IV. The second metatarsal is less compressed mediolaterally than metatarsals III and IV. Metatarsal II is $3.5 \mathrm{~mm}$ thick for most of its $82.1 \mathrm{~mm}$ length. The distal articular surface of metatarsal II present a well-developed gynglimus, which is different to the troodontids Saurornithoides mongoliensis (IVPP V 10597), Tochisaurus nemegtensis (after Kurzanov 1987) and Troodon formosus (after Wilson and Currie 1985). The troodontid Borogovia gracilicrus (alter Olsmolska 1987) presents a poorly-developed gynglimus, which is less-developed than in Pamparaptor. The third and fourth metatarsals are the longest elements in the metatarsus. The third metatarsal expend for all front of metatarsus and is not squeezed out by the second and fourth metatarsals throughout most of the midshaft region as in the troodontids Troodon (Wilson and Currie 1985) and Tochisaurus (Kurzanov and Osmolska 1991). This morphology is like Saurornithoides mongoliensis (Currie and Peng 1993). The distal end of the third metatarsal supports the largest phalanx of the foot. In posterior view, the distal end of metatarsal III is covered by metatarsals II and IV. A significant synapomorphy in troodontids is that the fourth metatarsal are the strongest element in the metatarsus. In Pamparaptor, the fourth metatarsals are very think in the distal end $(1 \mathrm{~mm})$, but in the proximal end are more robust $(3.5 \mathrm{~mm})$. The distal end and probably the middle shatf are mediolaterally compressed in this specimen. The first phalanx of the second digit is short $(16.6 \mathrm{~mm})$ and relatively robust. It is followed by the distinctive but longer (18.1 mm, maximum length) II-2. The ungual is strongly curved. The tip of the ungual for digit II was not found, but the base is quite deep, indicating a robust element. Phalanx III-1 is 26.5 in length, and is the longest phalanx preserved. The next phalanx, III-2, is a minor element (length $=17.4 \mathrm{~mm}$ ). The third and fourth phalanges are unknown. The fourth digit is the most incomplete, with only the distal end of IV-1? and proximal end of IV-2? being preserved in articulation.

\section{Comparations With the UnENLAgIINAE Neuquenraptor}

Here, we intensify the comparations with Neuquenraptor argentinus because it is the most complete pes into the Unenlagiins form. Pamparaptor micros shares with Neuquenraptor argentinus the following characteristics: metatarsal III strongly compressed and proximally pinched between metatarsals II and IV (present also in basals dromaeosaurids; see Novas and Pol 2005); metatarsal IV with a posterolateral flange (present also in basals dromaeosaurids; see Novas and Pol 2005); extensor sulcus on the proximal half of metatarsal II; metatarsal II with lateral expansion over the caudal surface of 
metatarsal III (originally considered an autapomorphy of N. argentinus by Novas and Pol 2005). Pamparaptor micros gen. et sp. nov. differs from Neuquenraptor in the proportions of the metatarsals and phalanges, especially those of digit II. In Pamparaptor, the metatarsals are considerably more slender and transversely compressed than in Neuquenraptor. Phalanx 1.III is more elongated than phalanx 2.III (Fig. 4). Curiously, metatarsals III and IV are subequal in length (Fig. 5), a morphology that is observed in troodontids and basal dromaeosaurids (Xu and Wang 2000), but not in Neuquenraptor and Rahonavis, in which these bones are unequal, and metatarsal III is longer than IV. In troodontids (e.g., Troodon formosus), metatarsal IV is usually more robust (Fig. 6).

In cranial view, the distal end of metatarsal II of Pamparaptor presents a sulcus directed medially, different to from Neuquenraptor in which the metatarsal is absent. The distal end of metatarsal III lacks of a ginglymoid articulation. In Pamparaptor micros, the expansion of the lateral crest of metatarsal IV begins proximally. The phalanges of digit II are subequal in length. In Neuquenraptor, pedal phalanx 2.I is bigger than 2.II, but in Pamparaptor, it is the reverse. The ungual phalanx of pedal digit II of Pamparaptor is proporcionally diferent than in Neuquenraptor. In Neuquenraptor and other derived Dromaeosaurids (Velociraptor, Dromaeosaurus, Deinonychus) the claw is lower and more acute than in Pamparaptor.

\section{COMPARISONS WITH TROODONTIDS}

The metatarsus of Pamparaptor shares with troodontids the small size and the slender structure. Moreover, metatarsals III and IV are subequal in length. However, proximally, the mediolateral widths of metatarsals IV and II are similar. In troodontids the metatarsal IV is the most robust. In Pamparaptor micros, the fourth digit is incomplete, which does not allow us to know which one is the longest finger.

On the other hand, the raptorial second digit is present in troodontids and dromaeosaurids. The size of this phalanx of digit II ranges between dromaeosaurids and troodontids. However, Russell and Dong (1993) described 26 characters that distinguising troodonts from dromaeosaurs. The characters 23 at 26 are of metatar-

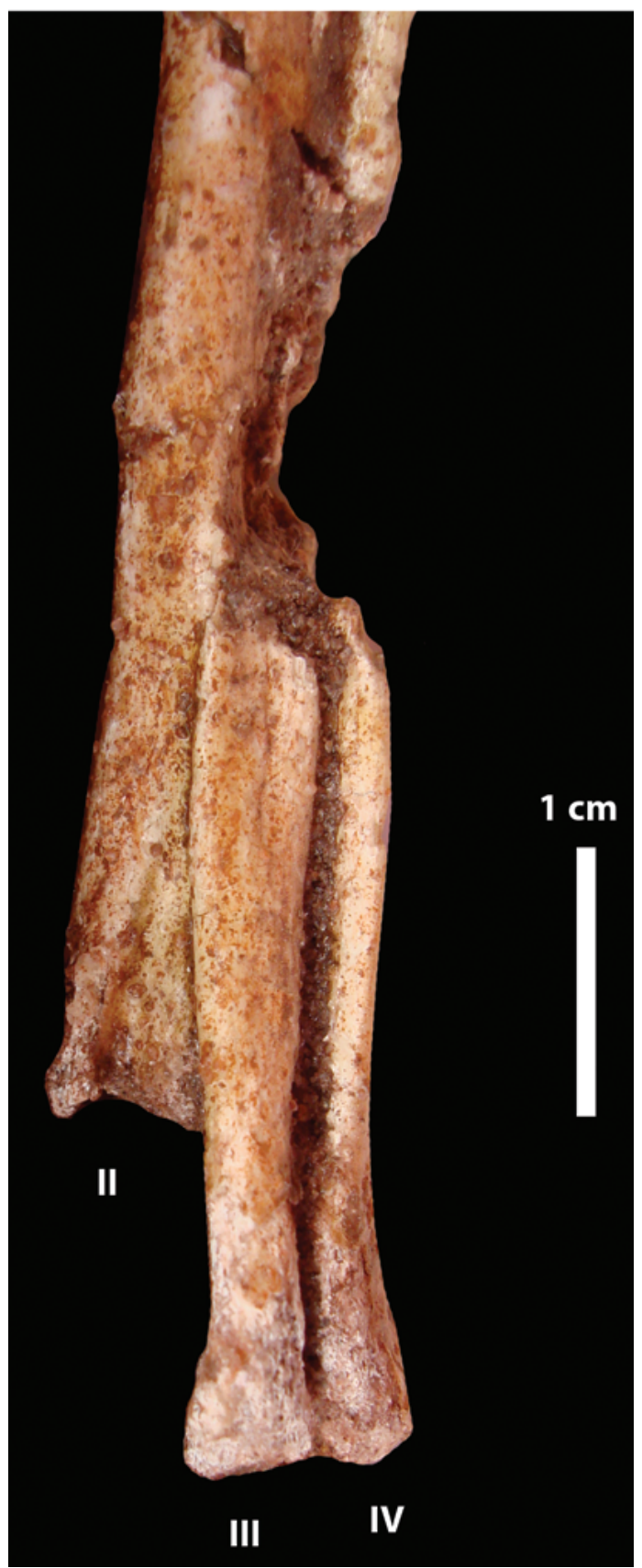

Fig. 5 - Distal end of metatarsals in anterior view.

sus: (23) Metatarsal III excluded proximally from extensor surface of metatarsus, proximal ramus splint-like (this character is absent in Pamparaptor); (24) Metatarsal IV more massive than the remainder of metatarsus (this character is doubful in Pamparaptor); (25) Distal articulations of metatarsals II and III smooth, not ginglymoid (this character is absent in Pamparaptor); metatarsal III bears posteroventral, tongue-like exten- 

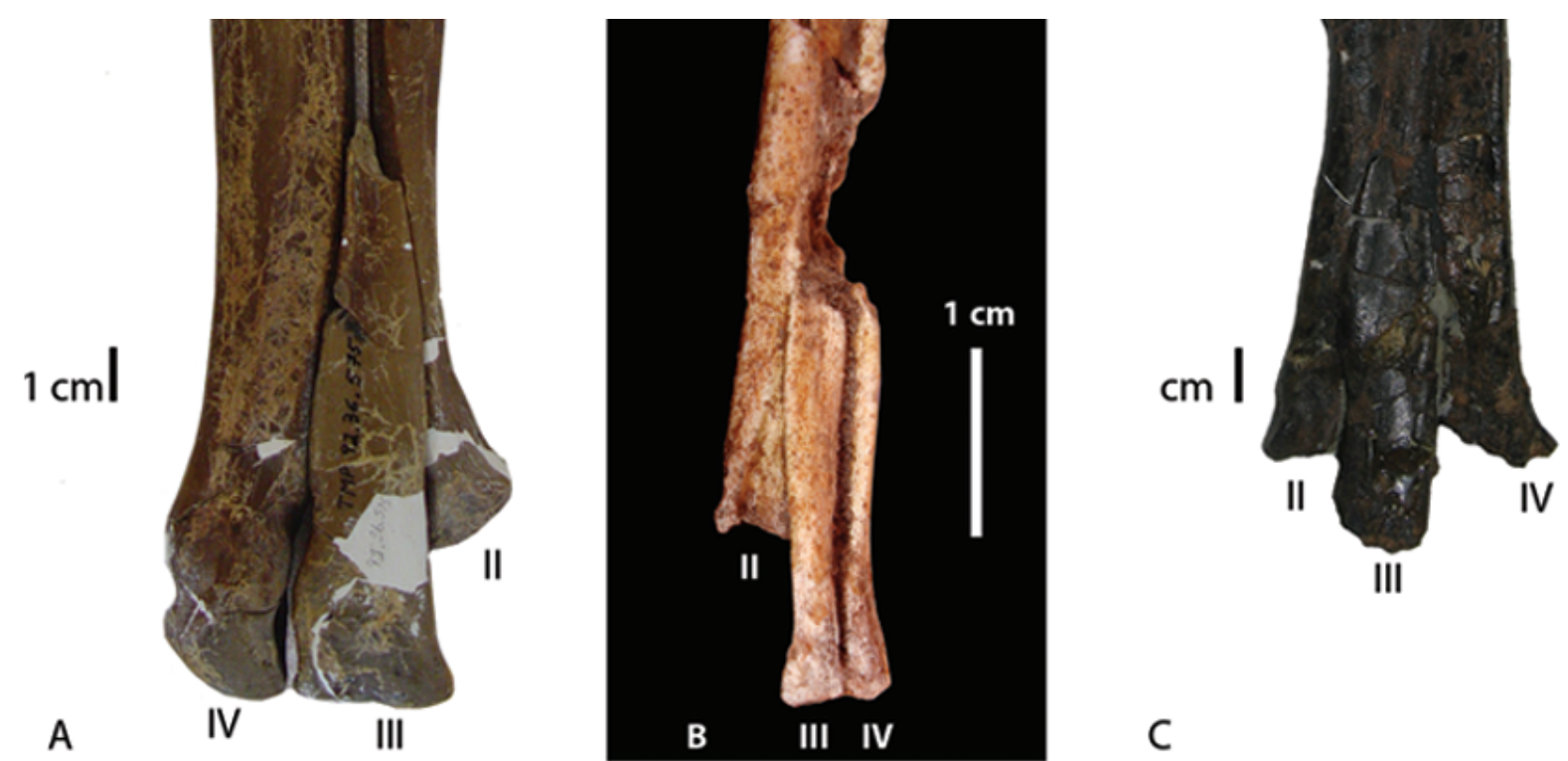

Fig. 6 - Distal end of metatarsals; A: Troodon; B: Pamparaptor; C: Neuquenraptor.

sion of articular surface; (26) Pedal phalanx II-1 longer than II-2 (this character is inverse in Pamparaptor); distal articulation of II-2 short (relative to the condition in dromaeosaurs; this character is absent in Pamparaptor); and II-3 shorter than II-1 and not strongly recurved (relative to the condition in dromaeosaurs; this character is absent in Pamparaptor).

\section{DISCUSSION AND CONCLUSIONS}

Originally, specimen MUCPv-1163 was referred to as Neuquenraptor by Porfiri et al. (2007) based on the similarities with this Patagonian form that was also documented in the same beds. In this context, specimen MUCPv-1163 was interpreted as a subadult stage of Neuquenraptor. However, complete technical preparation of the materials allowed confirming the absence of a displacement of metatarsal IV; therefore, there is a clear difference between MUCPv-1163 and Neuquenraptor, not related to their ontogenetic stage.

Available information suggests the presence of an endemic group of Deinonychosauria during Cenomanian times (Makovicky et al. 2005). Unfortunately, the record of deinonychosaurians from the Portezuelo Formation, which is the unit with the most complete record of theropods from South America, continues to be fragmentary, making difficult to solve the phylogenetic position of this clade.
The discovery of Pamparaptor supports a new lineage of Gondwanan deinonychosaurs, which is different from those present in Laurasia but with problematic interpretation of relationships. Nevertheless, the phylogenetic resolution of the Gondwanan dromaeosaurids is still problematic.

Neuquenraptor was considered as a junior synonym of Unenlagia (Makovicky et al. 2005, Turner et al. 2007) on the base that both came from the same stratigraphic and geographic provenances. However, based in the pedal phalanx 2.II of Unenlagia paynemili (Calvo et al. 2004), we consider that the pedal morphology of digit II of Neuquenraptor and Unenlagia is different. In Unenlagia paynemili, phalanx 1.II is longer than phalanx 2.II. as that present in Rahonavis and other dromaeosaurids. In Neuquenraptor, phalanx 1.II and 2.II are subequal. In Pamparaptor, phalanx 2.II is greater than phalanx 1.II. (Fig. 7). If Unenlagia paynemili's phalanx belonged to the same specimen, this would demostrate that at least Unenlagia paynemili and Neuquenraptor argentinus are different species; therefore, the Unenlagiinae clade is invalid and the basal politomy is unresolved.

The troodontids and basal dromaeosaurids pes presents several similarities (Xu and Wang 2000). Moreover, this convergence is present in the cranial morphology. The Gondwana raptors (unenlagiines?) Buitrerap- 

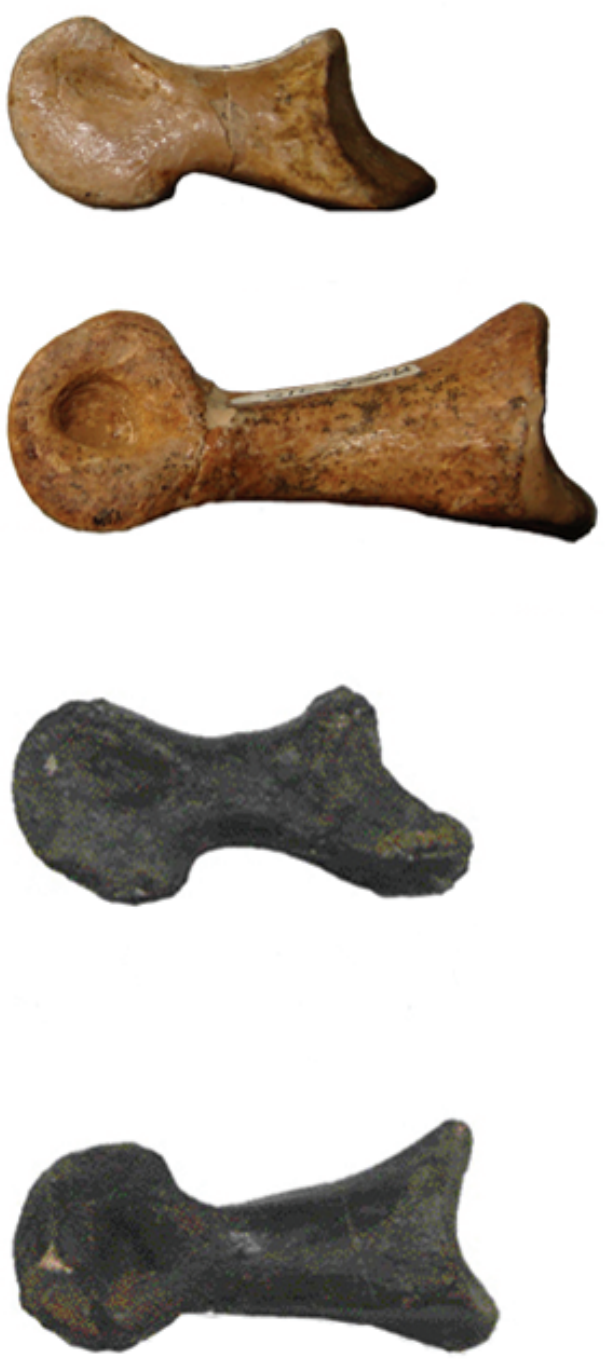

$1 \mathrm{CM}$

Fig. 7 - Phalanges of digit II of Unenlagia paynemili and Neuquenraptor argentinus in lateral view.

tor and Austroraptor, present low and elongated skulls as that of Byronosaurus. In this case, Pamparaptor presents metatarsal III at the same level of metatarsal IV, as it is seen in troodontids; however, metatarsal IV, of $P$. micros is less robust than that of troodontids.

Metatarsal IV is a very important tip in the comprehension of relationships about Pamparaptor, because if metatarsal IV is similar in size or more robust than metatarsal II add to the metatarsal III and IV are subequals in long we could be in presence of the firth troodontid dinosaur from South America. The characters present in Pamparaptor show a peculiar pedal construction with several characters that resemble the ones of troodontids. Nevertheless, the few evidence available and several characters checked and compared with troodontids demonstrate that Pamparaptor is a particular basal dromaeosaurid with a troodontid-like pes.

\section{ACKNOWLEDGMENTS}

We thank the technician Diego Rosales that found the specimen and the CePaLB team for the preparation of the material. Funding: The Pan American Energy company, Proyecto-Dino and Universidad Nacional del Comahue 04/I-122 and ANPCyT BID 1728-OC-PICT 2005-33984.

\section{RESUMO}

Aqui reportamos um novo pequeno terópodo deinonicosauriano, Pamparaptor micros gen. et sp. nov. do Cretáceo Superior da Patagônia, Argentina. Pamparaptor exibe uma estrutura pedal previamente desconhecida entre os deinonicosaurídeos da América do Sul. O novo material fornece uma nova evidência sobre a diversidade morfológica e taxonômica dos deinonicosaurídeos patagônicos. O Pamparaptor é o menor deinonicosaurídeo não-aviano patagônico, medindo provavelmente entre 0,50-0,70 metros de comprimento. A construção pedal lembra aquela de Troodontídeos ou Dromaeosaurídios basais. Entretanto, até agora, consideramos Pamparaptor um Dromaeosaurídeo patagônico peculiar com o pé similar ao de Troodontídeos.

Palavras-chave: Argentina, Lago Barreales, Dromaeosauridae, Cretáceo Superior, Patagônia, Unenlagiinae.

\section{REFERENCES}

Agnolín F, Novas FE AND Lio G. 2006. Neornithine bird coracoid from the Upper Cretaceous of Patagonia. Ameghiniana 43(1): 245-248.

Calvo JO, Porfiri JD And Kellner AWA. 2004. On a new maniraptoran dinosaur (Theropoda) from the Upper Cretaceous of Neuquén, Patagonia, Argentina. Arq Mus Nac, Rio de Janeiro 62: 549-566.

Calvo JO, Porfiri JD, Gonzalez Riga BJ and KellNER AWA. 2007. A new Cretaceous terrestrial ecosystem from Gondwana with the description of a new sauropod dinosaur. An Acad Bras Cienc 79: 529-541. 
Currie P And Peng J. 1993. A juvenile specimen of Saurornithoides mongoliensis from the Upper Cretaceous of northern China. Can J Earth Sci 30: 2224-2230.

JuÁrez VAlieri R, BerRondo M, CALVO J AND PORFIRI JD. 2008. First Abelisaurid postcranial remains from $\mathrm{Fu}-$ talognko quarry (Portezuelo Formation, Upper TuronianConiacian) and its implications. In: CALVO JO, JUÁREZ VAlieri R, PORFIRI JD AND Dos SAntos D (Eds), Libro de Resúmenes III Congreso Latinoamericano de Paleontología de Vertebrados, 127 p.

KURZANOV SM. 1987. Avimimidae and the problem with the origin of birds. Transactions, Joint Soviet, Mongolian Paleontological Expedition 31: 1-96.

KurZanov SM AND OsmolsKa H. 1991. Tochisaurus nemegtensis gen. et sp. n., a new troodontid (Dinosauria, Theropoda) from Mongolia. Acta Palaeont Polonica 36: 69-76.

Leanza HA, Apesteguía S, Novas FE And de LA FUENTE MS. 2004. Cretaceous terrestrial beds from the Neuquén Basin (Argentina) and their tetrapod assemblages. Cret Res 25: 61-87.

Makovicky PJ, Apesteguía S AND Agnolín FL. 2005. The earliest dromaeosaurid theropod from South America. Nature 437: 1007-1011. (doi:10.1038/nature03996).

Novas FE. 1997. Anatomy of Patagonykus puertai (Theropoda, Avialae, Alvarezsauridae). Illinois, J Vert Paleont 17: $137-166$.

Novas FE. 1998. Megaraptor namunhuaiquii gen. et sp. nov., a large clawed, Late Cretaceous from Patagonia. J Vert Paleont 18: 4-9.

Novas FE, Ezcurra MD AND Agnolín FL. 2006. Humerus of a basal abelisauroid theropod from the Late Cretaceous of Patagonia. Rev Mus Argentino Cienc Nat 8(1): 63-68.

Novas FE AND POL D. 2005. New evidence on deinonychosaurian dinosaurs from the Late Cretaceous of Patagonia. Nature 433: 858-861. (doi:10.1038/nature03285).
Novas Fe, Pol D, Canale Ji, Porfiri JD and Calvo JO. 2008. A bizarre Cretaceous theropod dinosaur from Patagonia and the evolution of Gondwanan dromaeosaurids. Proc R Soc B. 1-7. (doi:10.1098/rspb.2008.1554).

Novas FE AND PuerTA PF. 1997. New evidence concerning avian origins from the Late Cretaceous of Patagonia. Nature 387: 390-392. (doi:10.1038/387390a0).

OsmolsKA H. 1987. Borogovia gracilicrus gen. et sp. n. A new troodontid dinosaur from the Late Cretaceous of Mongolia. Acta Palaeont Polonica 32(1-2): 133-150, pls. 53,54 .

Porfiri JD, CAlVo JO, DOS SANTOS D AND JUÁREZ VALIERI RD. 2007. New record of Neuquenraptor (Dromaeosauridae, theropoda) from the Late Cretaceous of Patagonia. XXIII Jornadas Argentinas de Paleontología de Vertebrados, Resumenes, Trelew, 27 p.

Porfiri JD, CAlvo JO AND Novas FE. 2005. Hallazgo de un nuevo Theropoda del Cretácico Tardío en Lago Barreales, Neuquén, Patagonia, Argentina. II Congreso Latinoamericano de Paleontología de Vertebrados. Rio de Janeiro, Brasil, 209 p.

RUSSELL D AND DONG Z. 1993. A nearly complete skeleton of a new troodontid dinosaur from the Early Cretaceous of the Ordos Basin, Inner Mongolia, People's Republic of China. Can J Earth Sci 30: 2163-2173.

Turner A, Pol D, Clarke J, Erickson G ANd Norell MA. 2007. A basal dromaeosaurid and size evolution preceding avian flight. Science 317: 1378-1381. (doi:10.1126/science.1144066).

WILSON MC AND CURRIE PJ. 1985. Stenonychosaurus inequalis (Saurischia, Theropoda) from the Judith River(Oldman) Formation of Alberta: new findings on metatarsal structure. Can J Earth Sci 22: 1813-1817.

Xu X And Wang X. 2000. Troodontid-like pes in the Dromaeosaurid Sinornithosaurus. Paleontological Society of Korea, Special Publication No. 4, p. 179-188. 